ISSN 2414-1143

Научный альманах стран Причерноморья. 2019. Том 19. № 3

DOI 10.23947/2414-1143-2019-19-3-11-19

UDC 331.556 .2

\title{
THE EMPLOYMENT IMPACT ON THE REGION EXTERNAL MIGRATION
}

\author{
(C) Alexander V. Dzhioev
}

\author{
Laboratory of Applied Sociology and Conflictology, Vladikavkaz, Russian Federation \\ dzhioevsasha@gmail.com
}

Migration processes play a significant role in the socio-economic and demographic development of Russia. Over the past 20 years, the migration increase in the country's population has largely compensated for more than half of the natural decline in the population of the Russian Federation. However, in addition to external migration, internal migration has also become a subject of close attention - population movements between regions of the country, which is associated with its growing influence on the possibilities for the development of the population not only in individual settlements and cities, but also entire regions. Thus, in the Republic of North Ossetia-Alania, during the Soviet period, migration did not have any significant effect on the demographic situation. But with the collapse of the USSR, migration processes dramatically intensified. The development of negative trends in the demographic sphere of the Republic of North Ossetia-Alania, observed in the period 1992-2008 were caused by factors of interethnic instability, threats of terrorist acts and military actions in the Chechen Republic and the near abroad. By 2012, these factors were, in principle, leveled, but the flow of people leaving the region did not stop, which actualizes studies of other factors leading to the migration of the population of the Republic of North Ossetia-Alania to other regions. It is considered that migration processes are a characteristic of population mobility, reflecting its ability and readiness to change social status, professional affiliation and place of residence. Migration processes characterizing labor mobility of the population are caused by the needs of economy in the work of a certain content and also by the ability and readiness of the personality to changes in the essential characteristics of work. At the same time, the situation on the national, regional or local labor market is a factor affecting the parameters, nature and direction of migration. The article shows that the main reason for the negative migration processes in the Republic of North Ossetia-Alania in recent years has been the unfavorable situation in the labor market and growing unemployment among educated youth.

Key words: main characteristics of the labor market, rating of regions in terms of employment and unemployment, external region migration.

\section{[В.А. Джиоев Влияние занятости населения на внешнюю миграцию региона]}

Миграционные процессы играют значимую роль в социально-экономическом и демографическом развитии России. За последние 20 лет миграционный прирост населения страны в значительной степени компенсировал более половины естественной убыли населения Российской Федерации. Однако помимо внешней миграции, предметом пристального внимания стала и внутренняя миграция - перемещений населения между регионами страны, что связано с ее растущим влиянием на возможности развития народонаселения не только отдельных населенных пунктов и городов, но и целых регионов. Так, в Республике Северная Осетия-Алания в советский период миграция не оказывала сколь-нибудь существенного влияния на демографическую ситуацию. Но с распадом СССР миграционные процессы резко активизировались. Развитие негативных тенденций в демографической сфере Республики Северная Осетия-Алания, наблюдавшееся в период 1992-2008 гг. были обусловлены факторами межнациональной нестабильности, угрозами террористических актов и военными действиями в Чеченской Республике, Ближнем зарубежье. К 2012 году эти факторы были, в принципе, нивелированы, однако поток уезжающих из региона не прекратился, что актуализирует исследования других фракторов, ведущих к миграции населения Республики Северная Осетия-Алания в другие регионы. Принято считать, что миграционные процессы являются характеристикой мобильности населения, отражающей его возможность и готовность изменять социальный статус, профессиональную принадлежность и место проживания. Миграционные процессы, характеризующие трудовую мобильность населения, обусловлены потребностями экономики в труде определенного содержания, а также способностью и готовностью личности к изменениям в существенных характеристиках трудовой деятельности. В то же время ситуация на национальном, региональном или локальном рынке труда является фактором, влияющим на параметры, характер и направления миграции населения. В статье показано, что главной причиной, обусловливающей негативные миграционные процессы в Республики Северная Осетия-Алания, в последние годы является неблагоприятная ситуация на рынке труда и растущая безработица среди образованной молодежи.

Ключевые слова: основные характеристики рынка труда, рейтинг регионов по уровню занятости и безработицы, внешняя миграция региона. 
Alexander V. Dzhioev - Junior Research Fellow, Laboratory of Applied Sociology and Conflictology, Vladikavkaz Scientific Center, Russian Academy of Sciences, Vladikavkaz, Russian Federation.

Джиоев Александр Валерьевич - младший научный сотрудник Лаборатории прикладной социологии и конфрликтологии, Владикавказский научного центра Российской академии наук, г. Владикавказ, Российская Федерация.

The problems connected with the migration in Russia are shown in absolute majority of its regions with varying degrees of sharpness. In 2017 in 56 of 85 territorial subjects of the Russian Federation the negative balance of the migration was recorded. North Ossetia is a part of these regions. The excess of the people leaving the republic over the arriving ones began in 2002 and continues till today. According to the table 1, during 2002-2017 people left the republic on 47.5 thousand more than arrived from the outside. It is quite big loss of demographic and labor capacity of the republic especially as scales of the migration loss have been increasing.

Table 1

External migration of the population of the Republic Northern Ossetia-Alania in 2002-2017

\begin{tabular}{|c|c|c|c|}
\hline \multirow{2}{*}{ Years } & \multicolumn{3}{|c|}{ Migration flow, ths., person } \\
\cline { 2 - 4 } & Arrived & Left & Balance \\
\hline 2002 & & 5,8 & $-0,9$ \\
\hline 2003 & 4,9 & 6,3 & $-2,0$ \\
\hline 2004 & 4,3 & 6,2 & $-2,3$ \\
\hline 2005 & 3,9 & 5,8 & $-1,3$ \\
\hline 2006 & 4,5 & 5,9 & $-1,1$ \\
\hline 2007 & 4,8 & 6,4 & $-0,7$ \\
\hline 2008 & 5,7 & 7,1 & $-2,7$ \\
\hline 2009 & 4,4 & 6,6 & $-3,0$ \\
\hline 2010 & 3,6 & 7,3 & $-3,2$ \\
\hline 2011 & 4,1 & 12,8 & $-6,1$ \\
\hline 2012 & 6,7 & 14,6 & $-6,1$ \\
\hline 2013 & 8,5 & 14,9 & $-5,5$ \\
\hline 2014 & 9,4 & 12,8 & $-1,9$ \\
\hline 2015 & 10,9 & 13,7 & $-4,3$ \\
\hline 2016 & 9,4 & 12,3 & $-3,1$ \\
\hline 2017 & 9,2 & 12,2 & $-3,3$ \\
\hline Total & 8,9 & $\mathbf{1 5 0 , 7}$ & $-\mathbf{4 7 , 5}$ \\
\hline At an average annual & $\mathbf{1 0 3 , 2}$ & $\mathbf{9 , 4}$ & $\mathbf{- 3 , 0}$ \\
\hline
\end{tabular}

Source: Population shift of the Republic Northern Ossetia-Alania. Statistical bulletin. Vladikavkaz 2010-2018

In the first half of the analyzed period (2002-2009) the general negative balance of externally republican migration was 14.0 thousand people, or 1.75 thousand people a year. For the following same period (2010-2017) these indicators were much more large-scale - 33.5 thousand people and 4.19 thousand people, respectively. 
Since 2006 the Republic Northern Ossetia-Alania is included into the group of Russian regions in which natural increase does not block the scales of migration outflow therefore the population is reduced. By the time of the general population census of 2002, in the republic 713.0 thousand people lived, and in January, 2018 there were much less people (701.8 thousand). [12]. According to 2017 this group also includes the Republics of Kalmykia, Karachay-Cherkess; Transbaikal and Stavropol regions; Astrakhan, Irkutsk and Tomsk regions; Chukotka Autonomous Region [12].

Regular researches convincingly demonstrate that among the migrants who are actively leaving North Ossetia, there are a lot of youth, including experts with the higher and secondary professional education [14]. Respectively, the negative balance of migration, besides the reduction of the total number of the population, worsens sex and age and educational structure with the corresponding negative consequences [1-5].

Scales, intensity, structure and directions of migration flows are formed as a result of influence of a system of the interconnected social and political, social and economic, ethnoreligious and other factors. At the same time, among the reasons there are formations of character and intensity of migration processes, unemployment as a factor characterizing lack of an opportunity to realize the professional abilities and to receive worthy labor compensation in this region has a special place.

This reason is steadily noted in all social researches of problems and scales of migration. This conclusion is confirmed also by the system analysis of the data of official statistical reporting. On the basis of the analysis of the relevant statistical data the interrelation between the level of unemployment and characteristics of population shift is accurately traced. So, in absolute majority of territorial subjects of the Russian Federation with unemployment within the natural level, the positive balance of migration is fixed. Only two of ten regions with the least low coefficient of the general unemployment have negative balance of migration (table 2). According to the data of the second table, these two regions are Chukotka and the Lipetsk region. However, in the Lipetsk region the intensity of a stream is insignificant, and for 25 years the population has been leaving the Chukotka Autonomous Region because of adverse climatic conditions. In the absolute majority of the listed territorial subjects of the Russian Federation the positive balance of migration is fixed. In labor market of three regions (Moscow, the Moscow region and St. Petersburg) there was a favorable situation for a long time, and they are the largest migration recipients among the regions of the country.

Territorial subjects of the Russian Federation with the lowest level

Table 2 of unemployment, according to 2017

\begin{tabular}{|l|c|c|c|}
\hline & \multirow{2}{*}{$\begin{array}{c}\text { General coefficient of un- } \\
\text { employment, percent }\end{array}$} & \multicolumn{2}{|c|}{ Balance of migration } \\
\cline { 3 - 4 } & & Absolute data, person & $\begin{array}{c}\text { On 1000 people of the } \\
\text { population (\%) }\end{array}$ \\
\hline Moscow & 1,4 & 111020 & 9,0 \\
\hline St. Petersburg & 1,6 & 64546 & 12,2 \\
\hline $\begin{array}{l}\text { Chukotka Autonomous } \\
\text { Region }\end{array}$ & 2,9 & -656 & $-13,2$ \\
\hline Moscow region & 3,2 & 83097 & 11,2 \\
\hline Republic of Tatarstan & 3,5 & 4791 & 1,2 \\
\hline Tula region & 3,9 & 3794 & 2,5 \\
\hline
\end{tabular}


Научный альманах стран Причерноморья. 2019. Том 19. № 3

\begin{tabular}{|l|c|c|c|}
\hline Belgorod region & 3,9 & 2839 & 1,8 \\
\hline Tyumen region & 3,9 & 9102 & 2,5 \\
\hline Lipetsk region & 3,9 & -646 & $-0,6$ \\
\hline Kaluga region & 4,0 & 1631 & 1,6 \\
\hline
\end{tabular}

Source: Inspection of labor. Statistical bulletin. Moscow: 2018. Available at: http://www.gks.ru; Key indicators of social and economic development of territorial subjects of the Russian Federation in 2017. Statistical bulletin. Moscow: 2018. Available at: http://www.gks.ru

The opposite picture is observed in the regions with high coefficient of the general unemployment. As a rule, such regions are characterized by the intensive outflow of the population and human resources.

According to the data of the third table, the Republic Northern Ossetia-Alania in 2017 was a part of ten territorial subjects of the Russian Federation where the highest level of the general unemployment is recorded. In general, in these territorial subjects of the Russian Federation the high level of unemployment is fixed; and for many years these very subjects of Russia, except for Ingushetia, have been already the donors of labor for the other regions of the country.

It is remarkable that six of ten most excess working regions of Russia are in the North Caucasus, and in five of them the intensive outflow of population is fixed.

Territorial subjects of the Russian Federation with the highest level

Table 3 of unemployment, according to 2017

\begin{tabular}{|l|c|c|c|}
\hline \multirow{2}{*}{} & $\begin{array}{c}\text { General coefficient of } \\
\text { unemployment, percent }\end{array}$ & \multicolumn{2}{|c|}{ Balance of migration } \\
\cline { 3 - 4 } & & Absolute data, person & $\begin{array}{c}\text { On 1000 people of the } \\
\text { population (\%) }\end{array}$ \\
\hline Ingushetia & 26,4 & +1233 & 2,6 \\
\hline Republic of Tyva & 18,3 & -1055 & $-3,3$ \\
\hline Chechnya & 14,0 & -2749 & $-1,9$ \\
\hline Karachay-Cherkessia & 13,5 & -960 & $-2,1$ \\
\hline Kabardino-Balkaria & 10,4 & -2397 & $-2,8$ \\
\hline Zabaykalsky Krai & 10,7 & -7974 & $-7,4$ \\
\hline Altai Republic & 12,0 & -281 & $-1,3$ \\
\hline Dagestan & 12,0 & -12716 & $-4,2$ \\
\hline North Ossetia-Alania & 11,8 & -3271 & $-4,7$ \\
\hline Republic of Buryatia & 9,6 & -3426 & $-3,5$ \\
\hline
\end{tabular}

Source: Inspection of labor. Statistical bulletin. Moscow: 2018. Available at: http://www.gks.ru; Key indicators of social and economic development of territorial subjects of the Russian Federation in 2017. Statistical bulletin. Moscow: 2018. Available at: http://www.gks.ru 
As we see, migration policy is the most important direction of modern social and economic policy of the North Caucasian Federal District. In the Strategy of social and economic development of the district till 2025 it is noted that "the management of migration processes in the North Caucasian Federal District demands active participation of the federal center regarding development and implementation of the extensive program providing a complex of administrative, social, economic and cultural measures for quantitative and spatial regulation of migration flows [11].

The analysis of statistical data of dynamics and the extent of unemployment in the Republic Northern Ossetia-Alania demonstrate that in labor market of the region there was an intense situation which considerably worsens in recent years (table 4). During 2010-2017 the number of the employed people decreased by 47.7 thousand people and was 294.0 thousand people. According to the latest data in different spheres and branches of economy of North Ossetia $52.1 \%$ of an economically active population works. It is very low indicator of labor activity of able-bodied population of the republic.

Employment and unemployment of the population

Table 4 in the Republic Northern Ossetia-Alania in 2010-2017

\begin{tabular}{|l|c|c|c|c|}
\hline \multirow{2}{*}{ The employed } & 2010 & 2015 & 2016 & 2017 \\
\cline { 2 - 5 } & \multicolumn{4}{|c|}{ Absolute data, ths., person } \\
\hline The unemployed & 341,7 & 298,3 & 291,9 & 294,0 \\
\hline & 36,8 & 30,7 & 31,9 & 39,0 \\
\hline The employed & \multicolumn{3}{|c|}{ in percentage to the economically active population } \\
\hline The unemployed & 64,3 & 58,4 & 57,4 & 52,1 \\
\hline
\end{tabular}

Source: Inspection of labor. Statistical bulletin. Moscow: 2018. Available at: http://www.gks.ru; Key indicators of social and economic development of territorial subjects of the Russian Federation in 2017. Statistical bulletin. Moscow: 2018. Available at: http://www.gks.ru

For the assessment of nature of usage of labor capacity of the country or of the region absolute and relative characteristics of the unemployed are more information and capacious. In North Ossetia during 2010-2017 scales and intensity of unemployment changed for the worse. In 2017 the total number of the unemployed in North Ossetia was 39.0 thousand people, or $11.8 \%$ of an economically active population. To the standard measures, it is mass unemployment with the corresponding negative migration consequences.

Except employment figures and unemployment, the situation in labor market of Russia and in the regions is also estimated on the basis of other indicators, including the following indicators "duration of average time of job search" and "specific proportion of the unemployed who have been looking for job for 12 months and more". Federal government employment services regularly determine a rank (place) of the region among all territorial subjects of the Russian Federation by noted characteristics of labor market. In recent years the rank of North Ossetia constantly worsens and on the condition of 2017 according all main characteristics the region is in the end of the list of territorial subjects of the Russian Federation (table 5). 
The place of the Republic Northern Ossetia-Alania in the rating of a level of employment and duration of unemployment in the regions of Russia in 2010-2017

\begin{tabular}{|l|c|c|c|}
\hline & 2010 & 2013 & 2017 \\
\hline On the level of employment & 29 & 66 & 81 \\
\hline On the level of unemployment & 68 & 70 & 79 \\
\hline On the duration of average time of job search & 77 & 26 & 83 \\
\hline $\begin{array}{l}\text { On the proportion of the unemployed who have } \\
\text { been looking for job for 12 months and more }\end{array}$ & 64 & 21 & 82 \\
\hline
\end{tabular}

Source: Inspection of labor. Statistical bulletin. Moscow: 2018. Available at: http://www.gks.ru; Key indicators of social and economic development of territorial subjects of the Russian Federation in 2017. Statistical bulletin. Moscow: 2018. Available at: http://www.gks.ru

The average time of job search in the Republic Northern Ossetia-Alania makes 10.2 months (table 5). Longer than for this time people look for suitable job only in Ingushetia and in Karachay-Cherkessia. Countrywide this indicator is much lower; it is 7.6 months. The share of the unemployed who are looking for job longer than for a year in North Ossetia makes $51.6 \%$. The list of territorial subjects of the Russian Federation on this indicator is closed by the Republic of Tyva (53.9\%), Karachay-Cherkessia (61.9\%) and Ingushetia (71.3\%).

In general, in the North Caucasian Federal District in 2017 the general level of unemployment made $11.0 \%$ that is almost twice higher than a similar indicator in the country (5.2\%); and it is the worst indicator among eight federal districts of the Russian Federation [7].

It is well-known that unemployment is a youth problem. Of the total number of the unemployed in North Ossetia in 2018 45.7\% were made by youth at the age of 20-29 years. The share of the following age group (30-39) years, $21.8 \%$, is high (table 6).

Table 6

Dynamics of age structure of the unemployed population in the Republic Northern Ossetia-Alania in 2010-2018, in percentage

\begin{tabular}{|c|c|c|c|c|c|c|c|}
\hline \multirow{2}{*}{ Years } & Всего & \multicolumn{7}{|c|}{ Including ages } \\
\cline { 3 - 8 } & & before 20 & $20-29$ & $30-39$ & $40-49$ & $50-59$ & $60-72$ \\
\hline 2010 & 100 & 2,2 & 34,7 & 20,7 & 22,2 & 17,9 & 2,3 \\
\hline 2014 & 100 & 0,7 & 28,0 & 24,0 & 16,1 & 27,6 & 3,6 \\
\hline 2018 & 100 & 0,5 & 45,2 & 21,8 & 13,7 & 14,8 & 4,0 \\
\hline
\end{tabular}

Source: Inspection of labor. Statistical bulletin. Moscow: 2018. Available at: http://www.gks.ru; Key indicators of social and economic development of territorial subjects of the Russian Federation in 2017. Statistical bulletin. Moscow: 2018. Available at: http://www.gks.ru

According to the sixth table, the level of unemployment among youth at the age of 2029 years made $17.8 \%$, i.e. it is much more than in general among the population of the republic. These data confirm sharpness of problems of employment in the region, especially among youth. It is remarkable that the share of young people among the unemployed in the republic increases over time. According to the seventh table, in 2010-2018 adverse dynam- 
ics of decrease in average age of the unemployed against the background of the general growth of this indicator among occupied and labor is accurately traced.

Change of average age of labor, an employed and unemployed population of the Republic Northern Ossetia-Alania in 2010-2018

\begin{tabular}{|c|c|c|c|}
\hline \multirow{2}{*}{ Years } & \multicolumn{3}{|c|}{ Average age, years } \\
\cline { 2 - 4 } & Labor & Employed & Unemployed \\
\hline 2010 & 41,2 & 41,7 & 36,9 \\
\hline 2014 & 41,4 & 41,5 & 39,9 \\
\hline 2018 & 41,9 & 42,6 & 35,2 \\
\hline
\end{tabular}

Source: Inspection of labor. Statistical bulletin. Moscow: 2018. Available at: http://www.gks.ru; Key indicators of social and economic development of territorial subjects of the Russian Federation in 2017. Statistical bulletin. Moscow: 2018. Available at: http://www.gks.ru

The structure on education level (table 8) tells about the high labor potential of the unemployed. According to 2018 among unemployed population in North Ossetia the experts with professional education make $84.1 \%$, the experts with higher education make $42.7 \%$. It is a high rate of non-use of labor potential of experts. Especially negatively it is necessary to estimate a trend of increase of a share of jobless people with primary professional education (skilled workers).

Table 8

Structure of an unemployed population in North Ossetia according to the education level in 2010-2018, in percent

\begin{tabular}{|c|c|c|c|c|c|c|c|}
\hline Years & Total & \multicolumn{6}{|c|}{ Including people having education } \\
\cline { 3 - 8 } & & $\begin{array}{c}\text { higher } \\
\text { professional } \\
\text { education }\end{array}$ & $\begin{array}{c}\text { secondary } \\
\text { vocational } \\
\text { education }\end{array}$ & $\begin{array}{c}\text { elementary } \\
\text { vocational } \\
\text { education }\end{array}$ & $\begin{array}{c}\text { secondary } \\
\text { general } \\
\text { (full) } \\
\text { education }\end{array}$ & $\begin{array}{c}\text { compulsory } \\
\text { education }\end{array}$ & $\begin{array}{c}\text { without } \\
\text { compulsory } \\
\text { education }\end{array}$ \\
\hline 2010 & 100 & 25,0 & 21,0 & 12,0 & 29,8 & 7,6 & 4,6 \\
\hline 2014 & 100 & 33,4 & 25,6 & 17,6 & 22,0 & 1,4 & $\ldots$ \\
\hline 2018 & 100 & 42,7 & 23,1 & 18,3 & 14,3 & 1,6 & $\ldots$ \\
\hline
\end{tabular}

Source: Inspection of labor. Statistical bulletin. Moscow: 2018. Available at: http://www.gks.ru; Key indicators of social and economic development of territorial subjects of the Russian Federation in 2017. Statistical bulletin. Moscow: 2018. Available at: http://www.gks.ru

All the above noted scales and the structure of the unemployed testify about the necessity of development and realization of effective labor market policy of the region.

By expected calculations during the next period the number of graduates of educational institutions of professional education of different level in North Ossetia will make annually about 8 thousand people. It is expected that the vast majority of graduates in search of scope of their labor potential will appear in the regional labor market. In case of preservation of the high level of unemployment and a small chance to find suitable job quickly, the main part of graduates of the educational organizations will fill up the number of the migration flow from North Ossetia.

On the basis of the conducted research it is possible to draw the following conclusions: 
- the situation in the regional labor market is a factor actively influencing migration moods and forming migration processes;

- not only the rates of development of economy of the region, but also the solution of problems of demographic development in many respects depend on effective management of labor market;

- the purpose of ensuring of high and effective employment is achievable on the basis of implementation of investment policy of innovative updating of economy $[2,13]$, it has to be an integral part of any regional program focused on improvement of quality of life of people, achievement of economic and social progress of the population of the region.

\section{Лumepamypa}

1. Бадов А.Д., Бадов О.А., Кучмасова А.А. Миграции и социально-экономическая ситуация в Северной Осетии // Миграционные процессы: проблемы адаптации и интеграции мигрантов. Сборник материалов IV Международной научнопрактической конференции. 2018. С. 167-168.

2. Гуриева Л.К., Джиоев А.В. Миграционная политика как инструмент инновационного развития экономики: зарубежный опыт // Вестник Северо-Осетинского государственного университета имени Коста Левановича Хетагурова. 2014. № 4. С. 584588.

3. Гуриева Л.К Современные миграционные процессы населения в регионах Северо-Кавказского федерального округа // Экономика и предпринимательство. 2016. № 10-2 (75). С. 827-830.

4. Демографическая ситуация в Северной Осетии: факторы, прогнозы и механизм регулирования. Владикавказ, 2017.

5. Каберты Н.Г. Масштабы и интенсивность применения труда мигрантов в регионах Северо-Кавказского фредерального округа // Вестник Северо-Осетинского государственного университета имени Коста Левановича Хетагурова. 2017. № 2. С. 132-137.

6. Миграция населения РСО-Алания. Стат. бюллетень. Владикавказ 2010-2018 гг.

7. Обследование рабочей силы. Стат. сборник. М.: 2018. http://www.gks.ru

8. Обследование рабочей силы. Стат. сборники за 2010 - 2018 гг. http://www.gks.ru

9. Основные показатели социально-экономического развития субъектов РФ в 2017 году. Стат. бюллетень. М., 2018. http://www.gks.ru

10. Официальный сайт Комитета Республики Северная Осетия-Алания по занятости населения - http://www.trud15.ru;

11. Стратегия социально-экономического развития Северо-Кавказского федерального округа до 2025 года. Утверждена распоряжением Правительства Российской Федерации от 6 сентября 2010 года N 1485-р.

12. Численность и миграция населения РФ в 2017 г. стат. бюллетень. М., 2018.

13. Gurieva L.K. New economic geography as the theoretical platform of region innovative development // Mediterranean Journal of Social Sciences. 2015. T. 6. № 3. C. 19-26.

14. Dzhioev A.V., Gurieva L.K., Kamalov A.V. Development methods of the intellectual capital organizational component of the company // Гуманитарные и социальноэкономические науки. 2019. № 2. С. 142-146.

\section{References}

1. Badov A.D., Badov O.A., Kuchmasova A.A. Migratsii i sotsial'no-ekonomicheskaia situatsiia v Severnoi Osetii. Migratsionnye protsessy: problemy adaptatsii i integratsii migrantov. [Migration and socio-economic situation in North Ossetia. Migration processes: 
problems of adaptation and integration of migrants]. The collection of materials of the IV International Scientific Practical Conference. 2018. pp. 167-168 (in Russian).

2. Gurieva L.K., Dzhioev A.V. Migratsionnaia politika kak instrument innovatsionnogo razvitiia ekonomiki: zarubezhnyi opyt. [Migration policy as a tool for innovative development of the economy: foreign experience]. Bulletin of the North Ossetian State University named after Kosta Levanovich Khetagurov. 2014. No. 4. pp. 584-588 (in Russian).

3. Gurieva L.K. Sovremennye migratsionnye protsessy naseleniia v regionakh SeveroKavkazskogo federal'nogo okruga. [Modern migration processes of the population in the regions of the North Caucasus Federal District]. Economy and Entrepreneurship. 2016. No. 10-2 (75). pp. 827-830 (in Russian).

4. Demograficheskaia situatsiia v Severnoi Osetii: faktory, prognozy i mekhanizm regulirovaniia. [The demographic situation in North Ossetia: factors, projections and regulatory mechanism]. Vladikavkaz, 2017 (in Russian).

5. Caberty N.G. Masshtaby i intensivnost' primeneniia truda migrantov $\mathrm{v}$ regionakh Severo-Kavkazskogo federal'nogo okruga. [Scales and intensity of migrant labor in the regions of the North Caucasus Federal District]. Bulletin of the North Ossetian State University named after Kosta Levanovich Khetagurov. 2017. No. 2. pp. 132-137 (in Russian).

6. Migratsiia naseleniia RSO-Alaniia. [Migration of the population of RNO-Alania]. Statistical bulletin. Vladikavkaz 2010-2018 (in Russian).

7. Obsledovanie rabochei sily. [Labor inspection]. Statistical bulletin. Moscow: 2018. Available at: http://www.gks.ru

8. Obsledovanie rabochei sily. [Labor inspection]. Statistical bulletins for 2010-2018. Available at: http://www.gks.ru

9. Osnovnye pokazateli sotsial'no-ekonomicheskogo razvitiia sub'ektov RF v 2017 godu. [Main indicators of socio-economic development of the constituent entities of the Russian Federation in 2017]. Statistical bulletin. Moscow, 2018. Available at: http://www.gks.ru

10. Ofitsial'nyi sait Komiteta Respubliki Severnaia Osetiia-Alaniia po zaniatosti naseleniia [The official website of the Committee of the Republic of North Ossetia-Alania for Employment]. Available at: http://www.trud15.ru

11. Strategiia sotsial'no-ekonomicheskogo razvitiia Severo-Kavkazskogo federal'nogo okruga do 2025 goda. Utverzhdena rasporiazheniem Pravitel'stva Rossiiskoi Federatsii ot 6 sentiabria 2010 goda N 1485-r. [The strategy of socio-economic development of the North Caucasus Federal District until 2025 approved by the order of the Government of the Russian Federation of September 6, 2010 N 1485-p] (in Russian).

12. Chislennost' i migratsiia naseleniia RF v $2017 \mathrm{~g}$. [The number and migration of the population of the Russian Federation in 2017]. Statistical book. Moscow, 2018 (in Russian).

13. Gurieva L.K. New economic geography as the theoretical platform of region innovative development. [The development of innovative economic development]. The Mediterranean Journal of Social Sciences. 2015. V. 6. No. 3. pp. 19-26 (in Russian).

14.Dzhioev A.V., Gurieva L.K., Kamalov A.V. Development methods of the intellectual capital organizational component of the company. [Development methods of the intellectual capital organizational component of the company]. Humanitarian and social and economic sciences. 2019. No. 2. pp. 142-146 (in Russian).

28 June, 2019 